Vol. 14 (2005): 83-97.

\title{
Stream plant chemistry as indicator of acid sulphate soils in Sweden
}

Kaj Lax

Geological Survey of Sweden, PO Box 670,SE-751 28 Uppsala, Sweden, e-mail: kaj.lax@sgu.se

\begin{abstract}
Results from the biogeochemical mapping (roots of aquatic plants and Fontinalis antipyretica) conducted by the Geological Survey of Sweden (SGU) reflects the metal load of surface waters draining acid sulphate (AS) soils in Sweden. In this study, results from the biogeochemical, soil geochemical and Quaternary mapping programmes at SGU were used to investigate the impact of fine-grained deposits hosting AS soils on stream water trace element chemistry in two separate areas. In the area around Lake Mälaren, postglacial sediments contain the highest levels of most trace elements studied. Owing to the low $\mathrm{pH}$ of AS soils and subsequent leaching, levels of nickel (Ni), cobalt (Co), copper (Cu), sulphur (S), yttrium (Y), uranium (U), tungsten (W), and molybdenum (Mo) were significantly elevated in aquatic roots. Levels were lower in the Skellefteå area, which may be explained by lower concentrations in source deposits. Concentrations of arsenic $(\mathrm{As})$ and lead $(\mathrm{Pb})$ were normal or impoverished in biogeochemical samples from postglacial, finegrained sediment areas. Maps based on ratios ( $\mathrm{Ni}: \mathrm{Pb}$ or $\mathrm{Y}: \mathrm{Pb})$ in biogeochemical samples can, together with results from Quaternary mapping, be used to predict areas with AS soils in Sweden.
\end{abstract}

Key words: acid sulphate soils, water, biogeochemistry, metals, mapping

\section{Introduction}

Fine-grained sediments of marine/lacustrine origin occur below the highest shoreline in Sweden and Finland. Some of these sediments contain significant amounts of iron sulphides, and thus develop into acid sulphate (AS) soils on oxidation. Öborn (1994) estimated that $5 \%\left(1400 \mathrm{~km}^{2}\right)$ of arable land in Sweden is situated on active or potential acid sulphate soils. The exact extent of such soils has not been mapped in Sweden, but has been estimated from the extent of gyttja-containing soils in the soil map of the country, scale 1: 2000000 (Ekström 1953).

There are two main processes whereby sulphide-bearing, fine-grained sediments in Fennoscandia are exposed to atmospheric oxygen (Åström 1996). Isostatic land uplift is a natural process, and ranges from 0 to $9 \mathrm{~mm}$ per year in 
Sweden (Fredén 1994). In addition, many gyttjacontaining soils are suitable for agricultural purposes. Initially, however, most of these soils are low-lying and moist and artificial drainage is therefore required prior to farming. In a study conducted in western Finland, Åström and Åström (1997) concluded that stream water from catchments dominated by sulphidic sediments (> 80\% AS soils) is strongly enriched in, for example, Co (cobalt), Mn (manganese), $\mathrm{Ni}$ (nickel), $\mathrm{SO}_{4}^{2-}$ (sulphate), and Y (yttrium), but depleted in Fe (iron), $\mathrm{Pb}$ (lead), and $\mathrm{V}$ (vanadium). A large group of other elements (e.g. $\mathrm{Al}$ (aluminium), $\mathrm{Cu}$ (copper), $\mathrm{U}$ (uranium), and $\mathrm{Zn}$ (zinc)) were also enriched, but not to the same degree as the ones mentioned above. Similar results were reported by Åström and Deng (2003), with the additional conclusion that As (arsenic) and Mo (molybdenum) are not, or only weakly, enriched in stream water affected by AS soils.

Relatively little attention has been paid to the leaching of potentially harmful substances from active AS soils in Sweden, despite the assumed widespread distribution of such soils and the potential adverse effects on aquatic ecosystems. Most studies have focused on case studies from limited areas, e.g. Andersson et al. (1988), Manngård (1997), Öborn and Andersson (1999). These studies show that fine-grained sulphide-containing soils in Sweden cause elevated levels of several elements, e.g. As, Cd (cadmium), Co, Cu and $\mathrm{Ni}$, in minor streams. The findings are, except as regards As, similar to those of Aström and Åström (1997) and Åström and Deng (2003). Many of the potential environmental problems related to AS soils are poorly understood, and a need for enhanced knowledge regarding the spatial extent and severity of acidity has been expressed by Öborn (1994).

The current study attempts to describe some geochemical characteristics of AS soils, focusing on metal enrichment in the roots of aquatic plants. Sampling and analysis of the latter, together with water moss (Fontinalis antipyretica), constitute the biogeochemical mapping programme at the Geological Survey of Sweden (SGU). More than 36000 samples have been analysed in this ongoing survey, and the results can be used to predict occurrences of metal-enriched stream water from AS soils. This study therefore focuses on the chemical properties of biogeochemical samples from areas with known and probable occurrences of AS soils, in relation to those from unaffected areas with deposits typically not hosting AS soils. Results from Quaternary and soil geochemical mapping programmes have been used to classify the terrestrial sediments and investigate their general trace element geochemistry.

\section{Geochemical mapping}

In a study conducted in 1975, Brundin et al. (1987) found that roots of living, autochthonous aquatic plants (sedge and others species) in small, natural streams in northern Sweden reflected the geochemical properties of local bedrock better than conventional, organic stream sediments. However, aerial parts of plants were not considered a suitable sampling media, owing to poor correlation with local sediments. Largely based on those findings, SGU initiated a biogeochemical mapping programme in 1982, simultaneously with a geochemical mapping survey of glacial tills. Mineral exploration was initially the principal objective of the biogeochemical programme. Brundin (1980) pointed out that the method was well suited to environmental studies, e.g. relating to geomedical problems, as the results would to some degree reflect bioavailable concentrations of metals.

To date (2004), more than 36000 samples of aquatic plants have been collected and analysed. These biogeochemical samples mainly consist of aquatic roots of sedge (Carex spp.) and meadowsweet (Filipendula ulmaria), and whole-plant samples of the bryophyte water moss (Fontinalis antipyretica, also known as willow moss). Samples can be regarded as composite samples, since sampling is usually conducted along $50-100 \mathrm{~m}$ sections of the streams/ditches concerned. Many samples are mixed-species samples, while approx- 
imately $1 / 3$ include one species only. All samples are incinerated, and the resulting ash is analysed for total contents of Al, As, Ba (barium), Ca (calcium), $\mathrm{Cl}$ (chlorine), $\mathrm{Co}, \mathrm{Cr}$ (chromium), $\mathrm{Cu}, \mathrm{Fe}$, $\mathrm{K}$ (potassium), $\mathrm{Mg}$ (magnesium), $\mathrm{Mn}, \mathrm{Mo}, \mathrm{Na}$ (sodium), Ni, $\mathrm{P}$ (phosphorous), $\mathrm{Pb}, \mathrm{Rb}$ (rubidium), $\mathrm{S}$ (sulphur), Si (silica), Sr (strontium), Ti (titanium) U, V, W (tungsten), Y, Zn and Zr (zirconium) by XRF (X-ray fluorescence). Acid-leachable (7M $\mathrm{HNO}_{3}$ and aqua regia) concentrations of $\mathrm{Au}$ (gold), $\mathrm{Bi}$ (bismuth), $\mathrm{Cd}, \mathrm{Hg}$ (mercury), $\mathrm{Sb}$ (antimony) and Se (selenium) have been analysed by AAS (Atomic Absorption Spectrometry), ICP-AES (Inductively Coupled Plasma-Atomic Emission Spectrometry) or ICP-MS (Inductively Coupled Plasma-Mass Spectrometry) on 3000-8000 samples, depending on the element.

Most of the analysed elements exhibit good or excellent analytical quality, partly due to the preconcentration of trace elements originating from the ashing procedure. Overall, most elements have median precisions $< \pm 10 \%$ calculated as deviations of original samples from the duplicate + original sample mean value. Only $\mathrm{W}, \mathrm{U}$, and to some extent As suffer from somewhat low precision. This is however confined to low levels, $85 \%$ of As and $65 \%$ of $\mathrm{U}, \mathrm{W}$ duplicates have precisions better than $\pm 50 \%$. Only W and $\mathrm{U}$ are encountered in concentrations below detection limits for a significant number (approximately 1/3) of the samples.

Concurrently with biogeochemical mapping, a soil geochemical mapping programme was initiated. At first the programme was focused entirely on glacial till, but in the late 1990s other sediments (mainly fine-grained soils) were included as well. To date, more than 24000 till samples and some 600 other sediments have been analysed. All samples are C-horizon samples, in general from a depth of 0.7-1.0 m. Till samples are analysed for total (XRF) and acid-leachable contents (a combination of aqua regia and $7 \mathrm{M} \mathrm{HNO}_{3}$ ). Further descriptions of the geochemical sampling programmes at SGU, including quality control and quality assessment, can be found in Lax and Selinus (2005). All data used in this study have fulfilled stipulated requirements regarding precision and accuracy.

\section{Methods and description of areas}

The best coverage of detailed, modern Quaternary deposit data in Sweden is available for the Lake Mälaren region (west of Stockholm). Mapping has been conducted at a 1:50 000 scale, and clays have been classified as glacial and postglacial, in some areas with further subdivisions, i.e. gyttja-clay, clay-gyttja and gyttja have been used as separate mapping units. Gyttja is a fine-grained sediment formed in open water, and it contains $>20 \%$ of organic material (more or less decomposed residues, detritus or dead organisms). The content of organic material in gyttja-clay is $2-6 \%$ and in claygyttja 6-20\%. Quaternary maps of the area show that there are numerous areas covered with gyttjacontaining soils, some of which are known to have a $\mathrm{pH}<4$ and to contain the levels of sulphides required for classification as acid sulphate soils (Öborn 1994). Postglacial clays, which are much more frequent than gyttja-containing deposits, are also known to contain sulphides (e.g. Svantesson 1991). Like all other similar deposits in Sweden, these clays and the gyttja-containing deposits have formed since the last glaciation, marking the maximum extent of the Littorina Sea.

An area of $11250 \mathrm{~km}^{2}$ around Lakes Mälaren and Hjälmaren was selected as the primary area for the study (Fig. 1). Lakes cover $17 \%$ of the area. Terrestrial sediments are dominated by glacial tills and fine-grained sediments (glacial and postglacial clays). Gyttja-containing soils only cover $204 \mathrm{~km}^{2}$ (2\%) of the land area. Postglacial clays, which probably host AS soils as well, cover more than $10 \%$ of the land area $\left(1800 \mathrm{~km}^{2}\right)$. Most of the postglacial clays and gyttja-containing deposits are used for agricultural purposes. Ditching and drainage pipes in such areas lower the groundwater table and allow atmospheric oxygen to oxidize sulphides in the sediments.

A subset of the biogeochemical database, covering the study area, was extracted from the main database at SGU. The majority of the 1374 samples were root samples from sampling conducted in 1989-1991, mostly of Carex species. Less than $10 \%$ (101) were water moss samples, mainly ow- 


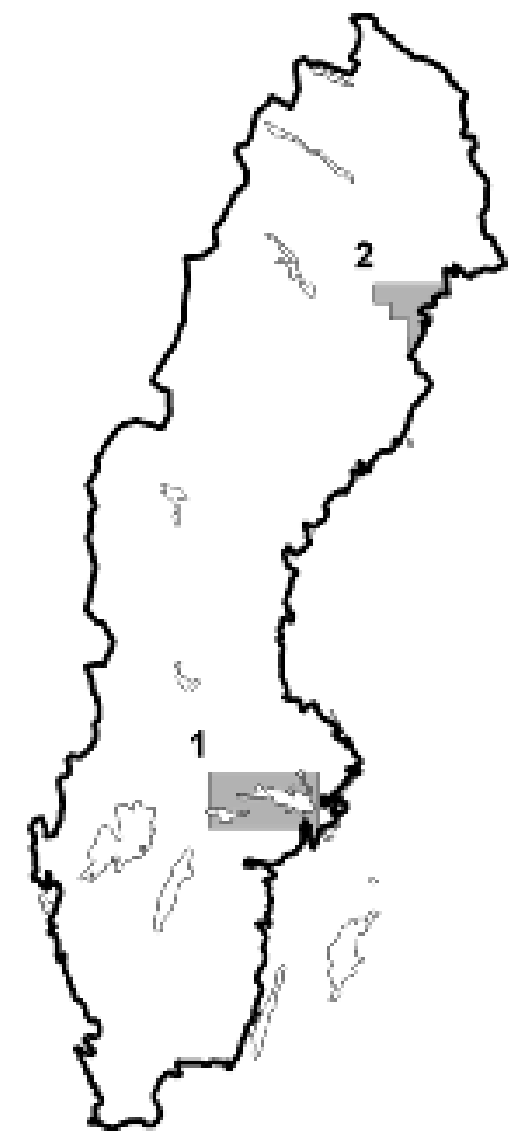

Fig. 1. Location of study areas. $1=$ the Lake Mälaren area, $2=$ the Skellefteå area.

ing to the widespread occurrence of fine-grained sediments in the area. Water moss is only encountered in streams with stony or rocky substrates.

For comparison, a second study area was selected. This area is situated along the coastline of the northern Baltic Sea, approximately between the towns of Skellefteå and Luleå (Fig. 1), and covers approximately $4200 \mathrm{~km}^{2}$. Here, 671 biogeochemical samples have been analysed following a sampling campaign conducted in 1999. Mapping of Quaternary deposits in the area has also been conducted at a 1:50 000 scale, but no distinction has been made between glacial and postglacial clays, nor have gyttja-containing deposits been mapped. As in the Mälaren area, biogeochemical samples mainly consist of Carex species roots (79\%). Prior to further processing of data, concentrations, which are stored as ash contents, were recalculated in dry weight terms.

One important aspect of the biogeochemical data set is potential differences between the elemental contents of species analysed. Such differences may, if large enough, cause severe problems in any attempt to differentiate the influence of AS soils from that of other soils. Therefore, all onespecies samples from the Mälaren area were subjected to a statistical evaluation for potential differences before subsequent treatment of the data.

The general geochemistry of the terrestrial sediments of both areas has been the subject of several studies (Melkerud et al. 1992, Eriksson et al. 1997, Reimann et al. 2003, Andersson 2004, Lax 2005). Despite large variations in sampling density, the Mälaren region is clearly anomalous in terms of high or elevated levels of several elements, including metals. For example, in comparison with other parts of Sweden, including the Skellefteå area in the present study, the ploughed layer of agricultural soils in the area around Lakes Mälaren and Hjälmaren contains elevated concentrations of several trace elements such as $\mathrm{Cr}, \mathrm{Cu}$, $\mathrm{Pb}$ and $\mathrm{Zn}$ (Eriksson et al. 1997). Some of the agricultural soils in the Mälaren region also contain $\mathrm{CaCO}_{3}$, which is reflected in elevated $\mathrm{pH}$ values (mostly > 6.3). The Skellefteå region is characterised by lower $\mathrm{pH}$ (usually $<5.3$ ), no detectable $\mathrm{CaCO}_{3}$, low $\mathrm{Pb}$ and $\mathrm{Zn}$, normal $\mathrm{Cu}$, and elevated As. The report published by Eriksson et al. (1997) does not contain data on several trace elements, e.g. Co, Ni. Therefore, in order to clarify the geochemical properties of soils in both areas, and the potential impact of other deposits than postglacial, fine-grained sediments, subsets were created from the SGU soil geochemical database. Soil geochemical mapping has been carried out by SGU in the western part of the Mälaren area and the entire Skellefteå area. The soil classification carried out during sampling was checked against the digital map of Quaternary deposits. Only samples that could be ascribed to a Quaternary deposit with a high degree of certainty, and belonging to one of the most common types of deposits (including gyt- 
Vol. 14 (2005): 83-97.

tja-containing deposits), were retained for further study. Most of the samples collected in the areas are till samples analysed on the $<0.063 \mathrm{~mm}$ fraction by ICP-MS on 7M nitric acid-leachable contents ( $\mathrm{n}=642$ and 405 in the Mälaren and Skellefteå areas, respectively). Samples belonging to glacial and postglacial clays, gyttja-containing deposits and overbank sediments were analysed with the same method, but on the $<2 \mathrm{~mm}$ fraction ( $\mathrm{n}=$ 123 and 39).

Öborn (1989) has described AS soil profiles from three sites within the current study areas. In the Mälaren area, two profiles were found to contain up to $0.85 \%$ of total $\mathrm{S}$ while concentrations of $\mathrm{C}$ (horizons below Ap) were typically around $1 \%$. In the Skellefteå area, results from one profile showed similar $\mathrm{C}$ and $\mathrm{S}$ contents, though overall $\mathrm{S}$ was somewhat higher. The $\mathrm{pH}$-values (air-dried) in the northern profile ranged from 2.8 to 4.3 , and in the southern profiles from 3.4 to 6.5 . In a study from western Finland, Österholm and Åström (2002) found that AS soils had not developed in deposits with $\leq 0.10 \% \mathrm{~S}$ or $\geq 4 \%$ organic $\mathrm{C}$ (carbon). Given that the profiles described by Öborn (1989) are typical of the present study areas, conditions are assumed to be adequate for the formation of AS soils in fine-grained deposits at several locations in both study areas.

Both areas are underlain by Proterozoic bedrock (Fredén 1994). Granitoids and metasediments are widespread, whereas basic rocks are subordinate. Mineralisations occur in both areas, as they are situated in the vicinity of two of Sweden's major ore districts, the Bergslagen and Skellefteå districts. Few or none of the mineralisations are likely to affect the geochemistry of the biogeochemical samples studied here, mainly owing to the types of mineralisation involved (mostly $\mathrm{Fe}$ oxides in Bergslagen). In addition, sulphide mineralisations, when present, are relatively small, and are not likely to cause any widespread pollution.

Agriculture is practised in both areas, and in counties around Lake Mälaren 80-90\% of farmland is used for crop production (SCB 2004). The Mälaren region is in part densely populated, whereas most areas in the Skellefteå region are sparsely populated. The Rönnskär smelter just south of the Skelleftea area is the only significant point source of metal pollution (Rühling et al. 1996). Elsewhere, sources are fairly small and contribute to a "diffuse" contamination that is assumed not to have caused any noteworthy pollution of soils.

Statistical calculations were performed using Statistica 6.0. For map production and GIS-related calculations, ArcGis 8.3 and MapInfo 7.0 were used.

\section{Results}

\section{The Mälaren area}

A study regarding possible species-induced differences in the biogeochemical data set from SGU has shown that some elements are enriched in one of the main species compared to the other species (Lax 2004). It is evident that, for most of the elements, the general tendency is Carex $<$ Filipendula $<$ Fontinalis. This enrichment effect, however, was only significant for a few elements. In water moss Mn was strongly enriched, as was also evident from the comparison of median concentrations in this study (Table 1). This is assumed to be explained by precipitation of Mn hydroxides onto the plants, a hypothesis supported by concurrently elevated levels of $\mathrm{Co}$, Ba and $\mathrm{Zn}$. It is also noteworthy that water moss had the lowest loss on ignition. Some of that phenomenon can be ascribed to occurrence of Mn hydroxides, but higher levels of elements such as $\mathrm{Si}, \mathrm{Al}, \mathrm{Ca}$ and $\mathrm{K}$ also contribute. These elements mainly reflect varying amounts of trapped mineral grains (quartz, feldspars). The presence of such minerogenic matter hampers the interpretation of data for some constituents, e.g. $\mathrm{Cr}$, but the adverse effects can be overcome by the use of normalisation procedures (Lax, unpublished results). For most elements ( $\mathrm{As}, \mathrm{Cu}, \mathrm{V}, \mathrm{Rb}, \mathrm{Mo}$, $\mathrm{W})$ the differences were small with respect to the data set as a whole (Table 1), confirming that the regional geochemistry of the area is the most important factor. The same conclusion is also evident 
Lax, K. Stream plant chemistry as indicator of acid sulphate soils

Table 1. Median concentrations in one-species biogeochemical samples from the Mälaren area. 10th and 90th percentiles for the entire population as reference values. Main elements expressed as oxides.

\begin{tabular}{|c|c|c|c|c|c|}
\hline & \multirow{2}{*}{$\begin{array}{l}\text { Filipendula } \\
\text { (median) }\end{array}$} & \multirow{2}{*}{$\begin{array}{l}\text { Fontinalis } \\
\text { (median) }\end{array}$} & \multirow{2}{*}{$\begin{array}{c}\text { Carex } \\
\text { (median) }\end{array}$} & \multicolumn{2}{|c|}{ Entire population } \\
\hline & & & & 10th $p$ & 90th $\mathrm{p}$ \\
\hline Loss on ignition $\%$ & 85.5 & 80.6 & 85.9 & 76.5 & 90.8 \\
\hline $\mathrm{Al}_{2} \mathrm{O}_{3} \%$ & 1.09 & 1.85 & 1.28 & 0.56 & 2.91 \\
\hline As mg kg-1 & 8.0 & 6.4 & 6.8 & 2.6 & 17.6 \\
\hline $\mathrm{BaO} \%$ & 0.014 & 0.031 & 0.010 & 0.007 & 0.046 \\
\hline $\mathrm{CaO} \%$ & 1.27 & 1.37 & 0.57 & 0.43 & 1.82 \\
\hline $\mathrm{Cl} \mathrm{mg} \mathrm{kg-1}$ & 1930 & 1324 & 689 & 395 & 2796 \\
\hline Co mg kg-1 & 19.5 & 39.2 & 18.2 & 7.7 & 71.7 \\
\hline Cr mg kg-1 & 7.0 & 10.6 & 8.2 & 3.6 & 16.3 \\
\hline $\mathrm{Cu} \mathrm{mg} \mathrm{kg}{ }^{-1}$ & 17 & 17 & 15 & 8 & 29 \\
\hline $\mathrm{Fe}_{2} \mathrm{O}_{3} \%$ & 2.01 & 2.23 & 2.43 & 0.86 & 5.83 \\
\hline $\mathrm{K}_{2} \mathrm{O} \%$ & 1.18 & 1.37 & 0.84 & 0.63 & 1.69 \\
\hline $\mathrm{MgO} \%$ & 0.94 & 0.47 & 0.36 & 0.25 & 1.01 \\
\hline $\mathrm{MnO} \%$ & 0.278 & 1.363 & 0.111 & 0.031 & 2.522 \\
\hline Mo mg kg-1 & 2.2 & 2.5 & 1.7 & 0.9 & 4.9 \\
\hline $\mathrm{Ni} \mathrm{mg} \mathrm{kg}^{-1}$ & 12.3 & 13.5 & 8.4 & 3.7 & 51.6 \\
\hline $\mathrm{Pb} \mathrm{mg} \mathrm{kg}^{-1}$ & 10.5 & 18.2 & 12.7 & 7.1 & 27.4 \\
\hline $\mathrm{P}_{2} \mathrm{O}_{5} \%$ & 0.454 & 0.440 & 0.280 & 0.199 & 0.813 \\
\hline $\mathrm{Rb}^{2} \mathrm{~g} \mathrm{~kg}{ }^{-1}$ & $33^{0.74}$ & 34 & 27 & 17 & 52 \\
\hline $\mathrm{S} \mathrm{mg} \mathrm{kg}^{-1}$ & 3523 & 2748 & 3253 & 2140 & 5419 \\
\hline $\mathrm{SiO}_{2} \%$ & 3.8 & 6.3 & 5.1 & 1.7 & 9.9 \\
\hline Sr mg kg-1 & 58 & 38 & 19 & 14 & 66 \\
\hline $\mathrm{TiO}_{2} \%$ & 0.0455 & 0.0767 & 0.0600 & 0.0194 & 0.1222 \\
\hline $\mathrm{U} \mathrm{mg} \mathrm{kg}^{-1}$ & 9.8 & 6.2 & 3.5 & 1.6 & 21.6 \\
\hline $\mathrm{V} \mathrm{mg} \mathrm{kg}^{-1}$ & 22 & 29 & 21 & 11 & 43 \\
\hline W mg kg-1 & 2.1 & 2.0 & 0.9 & 0.5 & 4.1 \\
\hline $\mathrm{Y} \mathrm{mg} \mathrm{kg}^{-1}$ & 26 & 27 & 14 & 7 & 54 \\
\hline $\mathrm{Zn} \mathrm{mg} \mathrm{kg-1}$ & 125 & 147 & 74 & 46 & 307 \\
\hline $\mathrm{Zr} \mathrm{mg} \mathrm{kg}$ & 17 & 23 & 18 & 7 & 40 \\
\hline $\mathrm{n}$ & 140 & 101 & 156 & 397 & 397 \\
\hline
\end{tabular}

in published maps of different regions (e.g. Holmberg et al. 1999); despite occasional clustering of different species, geochemical spatial distribution patterns are not significantly affected.

The Quaternary deposits in the area differed from each other with respect to their geochemical properties (Table 2). Compared to till, the other sediments were consistently enriched in metals like Ni, Co and Y. Differences between the glacial and postglacial clays were small but significant (Mann-Whitney U-test, $\mathrm{P}<0.05$ ) for most elements. The postglacial clays contained higher concentrations of As, Ba, Cr, Cu, Mo, Ni, Rb, Se, Tl, $\mathrm{V}$ and $\mathrm{Zn}$, whereas $\mathrm{pH}$ and $\mathrm{Sn}$ and $\mathrm{Th}$ contents were lower. Compared to postglacial clays, gyttjacontaining soils were enriched in Mo, Se and W, and had lower $\mathrm{pH}$ (Fig. 2) and lower concentrations of $\mathrm{V}$ and $\mathrm{Cr}$. The acid nature of the gyttjacontaining soils (three soils $<\mathrm{pH} 4$ ) supports the interpretation of those samples as representing AS soils. It should be stressed that $\mathrm{pH}$ may vary greatly in AS soil pedons; in profiles from selected AS soils in Sweden, Öborn (1989) reported values between 3.1 and 5.6 at depths typical of SGU sampling $(0.8-1.0 \mathrm{~m})$. Furthermore, some of the soils classified as postglacial clays have a signature that correlates with typical gyttja-containing soils, e.g. low $\mathrm{pH}$ and enriched in Mo, Se and W. These samples are thus interpreted as probably representing AS soils. It should be noted that, owing to a lack of data regarding sulphur and carbon contents, this interpretation cannot be verified with certainty. Till, which is used for comparison as it is the most common type of deposit in Sweden (Fredén 1994), had (with the exception of W and Sn) the lowest median concentrations of the compared types of deposits. This is mainly explained by the use of the $<0.063 \mathrm{~mm}$ fraction in tills. Fine-grained sedi- 
Vol. 14 (2005): 83-97.

Table 2. Median concentrations ( $\mathrm{mg} \mathrm{kg}^{-1}$ dry weight except where otherwise stated) of trace elements in different types of Quaternary deposits in the Mälaren study area. Analytical method ICP-MS + 7 $\mathrm{M} \mathrm{HNO}_{3}$. Highest median concentrations highlighted in bold.

\begin{tabular}{|c|c|c|c|c|c|}
\hline & Glacial clay & Postglacial clay & $\begin{array}{l}\text { Gyttja-containing } \\
\text { soils }\end{array}$ & $\begin{array}{l}\text { Overbank } \\
\text { sediments }\end{array}$ & Till \\
\hline $\mathrm{Ag}$ & 0.17 & 0.19 & 0.18 & 0.14 & 0.06 \\
\hline As & 3.4 & 6.2 & 5.9 & 4.5 & 1.2 \\
\hline $\mathrm{BaO}(\%)$ & 0.009 & 0.014 & 0.010 & 0.007 & 0.002 \\
\hline $\mathrm{Bi}$ & 0.48 & 0.49 & 0.46 & 0.41 & 0.17 \\
\hline $\mathrm{Cd}$ & 0.14 & 0.16 & 0.17 & 0.13 & 0.06 \\
\hline Co & 13 & 14 & 12 & 12 & 4 \\
\hline $\mathrm{Cr}$ & 36 & 44 & 37 & 39 & 11 \\
\hline $\mathrm{Cu}$ & 24 & 28 & 24 & 23 & 6 \\
\hline $\mathrm{La}$ & 50 & 51 & 44 & 58 & 20 \\
\hline $\mathrm{Li}$ & 28 & 32 & 30 & 27 & 10 \\
\hline Мо & 0.34 & 0.51 & 0.86 & 0.51 & 0.29 \\
\hline $\mathrm{Ni}$ & 22 & 29 & 28 & 27 & 6 \\
\hline $\mathrm{Pb}$ & 22 & 21 & 19 & 20 & 8 \\
\hline $\mathrm{pH}$ & 6.9 & 6.6 & 4.3 & 6.2 & 5.3 \\
\hline $\mathrm{Rb}$ & 45 & 61 & 56 & 56 & 12 \\
\hline $\mathrm{Se}$ & 0.28 & 0.34 & 0.49 & 0.38 & 0.20 \\
\hline $\mathrm{Sn}$ & 0.36 & 0.32 & 0.33 & 0.20 & 0.43 \\
\hline $\mathrm{Sr}$ & 27 & 28 & 22 & 26 & 7 \\
\hline Th & 19 & 18 & 17 & 16 & 11 \\
\hline $\mathrm{Tl}$ & 0.30 & 0.38 & 0.35 & 0.31 & 0.10 \\
\hline U & 4.5 & 4.0 & 4.1 & 5.6 & 2.4 \\
\hline $\mathrm{V}$ & 46 & 52 & 41 & 42 & 17 \\
\hline W & 0.06 & 0.06 & 0.10 & 0.07 & 0.14 \\
\hline $\mathrm{Y}$ & 32 & 30 & 29 & 38 & 12 \\
\hline $\mathrm{Zn}$ & 85 & 104 & 93 & 110 & 29 \\
\hline $\mathrm{n}$ & 43 & 56 & 7 & 6 & 642 \\
\hline
\end{tabular}

Fig. 2. Box plot of $\mathrm{pH}$ (dried samples + deionised water) in Quaternary deposits in the Mälaren area. Clay g = glacial clay, Clay pg $=$ postglacial clay, Gyttja $\mathrm{cs}=$ gyttja-containing sediments .

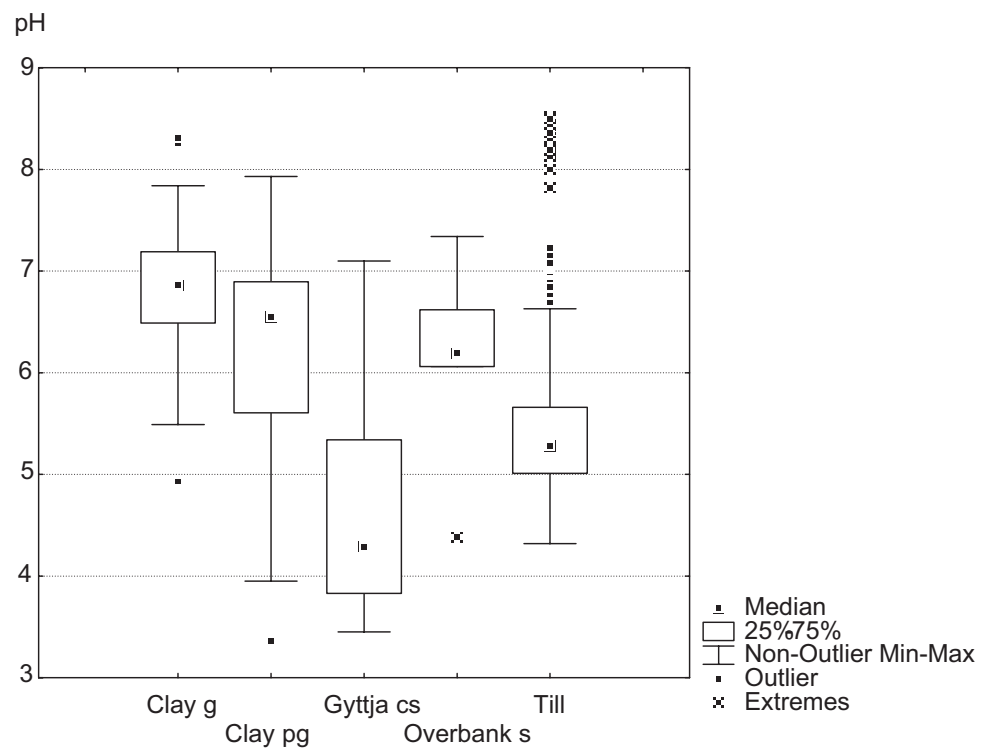


Lax, K. Stream plant chemistry as indicator of acid sulphate soils

Table 3. Median total concentrations of elements in till and biogeochemical samples from the Mälaren study area. Enrichment factor calculated as the biogeochemical samples/till ratio. Table sorted in ascending enrichment factor order.

\begin{tabular}{|c|c|c|c|}
\hline & Till & Biogeochemical samples & Enrichment factor \\
\hline Zr mg kg-1 & 344 & 20 & 0.06 \\
\hline $\mathrm{SiO}_{2} \%$ & 67 & 5 & 0.08 \\
\hline $\mathrm{Al}_{2} \mathrm{O}_{3} \%$ & 11.3 & 1.5 & 0.13 \\
\hline $\mathrm{TiO}_{2} \%$ & 0.41 & 0.06 & 0.15 \\
\hline $\mathrm{Rb}_{\mathrm{mg} \mathrm{kg}} \mathrm{kg}^{-1}$ & 114 & 33 & 0.29 \\
\hline $\mathrm{BaO} \%$ & 0.050 & 0.015 & 0.30 \\
\hline $\mathrm{W} \mathrm{mg} \mathrm{kg}^{-1}$ & 6 & 2 & 0.31 \\
\hline Cr mg kg-1 & 28 & 9 & 0.31 \\
\hline $\mathrm{Sr} \mathrm{mg} \mathrm{kg}^{-1}$ & 99 & 38 & 0.39 \\
\hline $\mathrm{K}_{2} \mathrm{O} \%$ & 2.78 & 1.28 & 0.46 \\
\hline $\mathrm{MgO} \%$ & 1.14 & 0.58 & 0.51 \\
\hline $\mathrm{Pb} \mathrm{mg} \mathrm{kg}^{-1}$ & 26 & 13 & 0.51 \\
\hline $\mathrm{Y} \mathrm{mg} \mathrm{kg}^{-1}$ & 41 & 23 & 0.57 \\
\hline $\mathrm{V} \mathrm{mg} \mathrm{kg-1}$ & 37 & 23 & 0.64 \\
\hline $\mathrm{Fe}_{2} \mathrm{O}_{3} \%$ & 2.83 & 2.36 & 0.84 \\
\hline $\mathrm{CaO} \%$ & 1.35 & 1.13 & 0.84 \\
\hline $\mathrm{Ni} \mathrm{mg} \mathrm{kg-1}$ & 11 & 14 & 1.21 \\
\hline $\mathrm{U} \mathrm{mg} \mathrm{kg}^{-1}$ & 5 & 8 & 1.56 \\
\hline As mg kg-1 & 5 & 9 & 1.70 \\
\hline Mo mg kg-1 & 1 & 2 & 1.88 \\
\hline $\mathrm{Cu} \mathrm{mg} \mathrm{kg}^{-1}$ & 8 & 19 & 2.29 \\
\hline $\mathrm{Zn} \mathrm{mg} \mathrm{kg}{ }^{-1}$ & 42 & 101 & 2.41 \\
\hline Co mg kg-1 & 8 & 22 & 2.68 \\
\hline $\mathrm{P}_{2} \mathrm{O}_{5} \%$ & 0.12 & 0.42 & 3.55 \\
\hline $\mathrm{MnO} \%$ & 0.04 & 0.29 & 7.47 \\
\hline $\mathrm{Cl} \mathrm{mg} \mathrm{kg}^{-1}$ & 91 & 1746 & 19.18 \\
\hline $\mathrm{S} \mathrm{mg} \mathrm{kg}^{-1}$ & 137 & 3470 & 25.27 \\
\hline
\end{tabular}

ments are sieved to $<2 \mathrm{~mm}$, but the material that is analysed is likely to be of smaller grain size than the till samples. The coarser material in the till samples dilutes the leachable metal contents, owing to the presence of silicate minerals (quartz, feldspars etc.) that contain low concentrations of metals. Furthermore, any metal present in such minerals is likely to be difficult to dissolve in the nitric acid used. The general sequence for trace elements (partly based on data not shown here) is clays and gyttja-containing deposits>overbank sed iments $>$ till $>$ glacifluvial deposits. Tills, however, usually contained the highest maximum concentrations, showing that the chemistry of the parent bedrock causes local (or regional) enrichment.

Results from total analyses of till data in the area were compared with biogeochemical data in order to investigate "enrichment factors" for the aquatic plants concerned. Only total contents were used, as no acid leach has been performed on biogeochemical samples. The results revealed that most elements were far more enriched in the $<0.063 \mathrm{~mm}$ fraction of till than in the biogeochemical samples (Table 3). Elements like $\mathrm{Zr}$ and $\mathrm{Si}$, which mostly occur in very weathering-resistant minerals, and are immobile in soils and water, are enriched by a factor of more than ten in till. Several other elements that are assumed to be fairly immobile were also less abundant in biogeochemical samples, i.e. $\mathrm{Al}, \mathrm{Ti}, \mathrm{Cr}$ and $\mathrm{K}$. Sulphur and $\mathrm{Cl}$, on the other hand, were very strongly enriched in the aquatic plant samples, with median concentrations resulting in enrichment factors of 25 and 19, respectively. The high enrichment factor for manganese is not regarded as a consequence of genuine uptake, but is most likely a result of secondary $\mathrm{Mn}$ (hydr)oxides. Trace elements $\mathrm{Co}$ and $\mathrm{Zn}$ are assumed to be in part precipitated on the surface of 
Vol. 14 (2005): 83-97.

Mn hydroxides, which is revealed by $r_{s}$ coefficients of 0.68 and 0.65 , respectively, with Mn (Table 4). The occurrence of Fe and Mn (hydroxides) and of minerogenic matter in samples is not an unknown problem. A statistical method based on a stepwise multiple regression procedure has been devised in order to minimise the effect of such substances on trace element contents (Selinus 1983). The multiple regression approach, however, is only applicable to results expressed as concentrations in ash; here concentrations on a dry weight basis are used and the data are not corrected.

The correlation matrix (Table 4) for the biogeochemical data set also confirmed a relationship between elements related to minerogenic matter and ash content. Aluminium, $\mathrm{Cr}, \mathrm{Si}, \mathrm{Ti}, \mathrm{V}$ and $\mathrm{Zr}$ correlated strongly with each other and with ash content $\left(r_{s}>0.7\right)$. For Ba the correlation was somewhat lower, which is explained by the additional presence of the Mn hydroxide factor discussed above. Iron correlated strongly with $\mathrm{V}$ and As. The geochemistry of $\mathrm{V}$ is very similar to that of $\mathrm{Fe}$, and the significant positive correlation between As and $\mathrm{Fe}$ indicates that As has occurred dissolved in surface water, subsequently adsorbed to Fe hydroxyoxides. The effect of iron and other metal oxides on mobility of As is well documented (e.g. Smedley and Kinniburgh 2005). A group of trace elements displayed significant positive correlations: $\mathrm{W}, \mathrm{Ni}, \mathrm{Co}, \mathrm{Y}, \mathrm{Mo}, \mathrm{U}, \mathrm{Cu}$ and $\mathrm{Zn}$. Most of these elements have been shown to be enriched in surface waters draining AS soils (Åström and Åström 1997, Åström and Deng 2003).

The biogeochemical samples were assigned to groups depending on the type of Quaternary deposit at the sampling site. Initial subdivisions of the Quaternary deposits were reduced in order to obtain a manageable number of groups: peat, bedrock, sand, till, silt, overbank sediments, glacial clay, postglacial clay and gyttja-containing deposits. Only three samples could not be classified. Although it is likely to introduce a statistical "noise" into the resulting data set, no account was taken of soils upstream in the catchments. There were two main reasons for this: first, the local soil at the sampling site is assumed to be more important for the composition of surface water in small ditches and natural streams. The results reported by Åström and Åström (1997) confirm that assumption. Secondly, the existing geographical data set was not accurate enough; several streams and ditches were not available in the 1:50 000 scale layer used. Furthermore, it has been shown that not even a comprehensive data set for watercourses guarantees that the geographical extent of small drainage areas can be correctly delineated, unless time-consuming on-site investigations are undertaken (Lång and Thunholm 2002).

The results showed that, in general, peat, bedrock, sand and till were characterised by low median concentrations in the biogeochemical samples, whereas fine-grained sediments caused enrichment (Table 5). Overbank sediments, which are formed by a mixture of deposits occurring upstream, are only characterised by elevated levels of $\mathrm{Mn}, \mathrm{Ni}$ and $\mathrm{Zn}$. Though interpreted as reflecting mainly natural levels, pollution cannot be entirely ruled out as a source of these elements. Gyttjacontaining deposits cause elevated concentrations, in particular, of Ni, W, Co, Cu and Y (Fig. 3). Median concentrations of these elements were more than twice the median for the entire population, whereas the equivalent medians for $\mathrm{Cl}, \mathrm{S}, \mathrm{U}$ and Zn were 1.5-2 times higher. The group of elements concerned contains the same elements as Åström and Åström (1997) found were elevated in surface waters of catchments dominated by AS soils in western Finland. Median levels in AS catchments were up to 31 times higher (Y) than in non-AS reference waters.

Postglacial clays are also obvious sources of metals, but not to the same extent as gyttja-containing deposits. It should be noted that all groups contain samples that were clearly elevated for most metals, e.g. Ni (Fig. 3). Such samples may be affected by AS soils occurring upstream or by anthropogenic contamination. Due to concurrently elevated levels of several elements in the $\mathrm{Ni}, \mathrm{Co}$, $\mathrm{Cu}, \mathrm{U}, \mathrm{S}, \mathrm{W}$ association, the former explanation is proposed as the most common.

Lead was not significantly enriched in root samples from areas with fine-grained sediments. The spatial distribution pattern for $\mathrm{Pb}$ in biogeochemical samples was actually the inverse of those 
Lax, K. Stream plant chemistry as indicator of acid sulphate soils

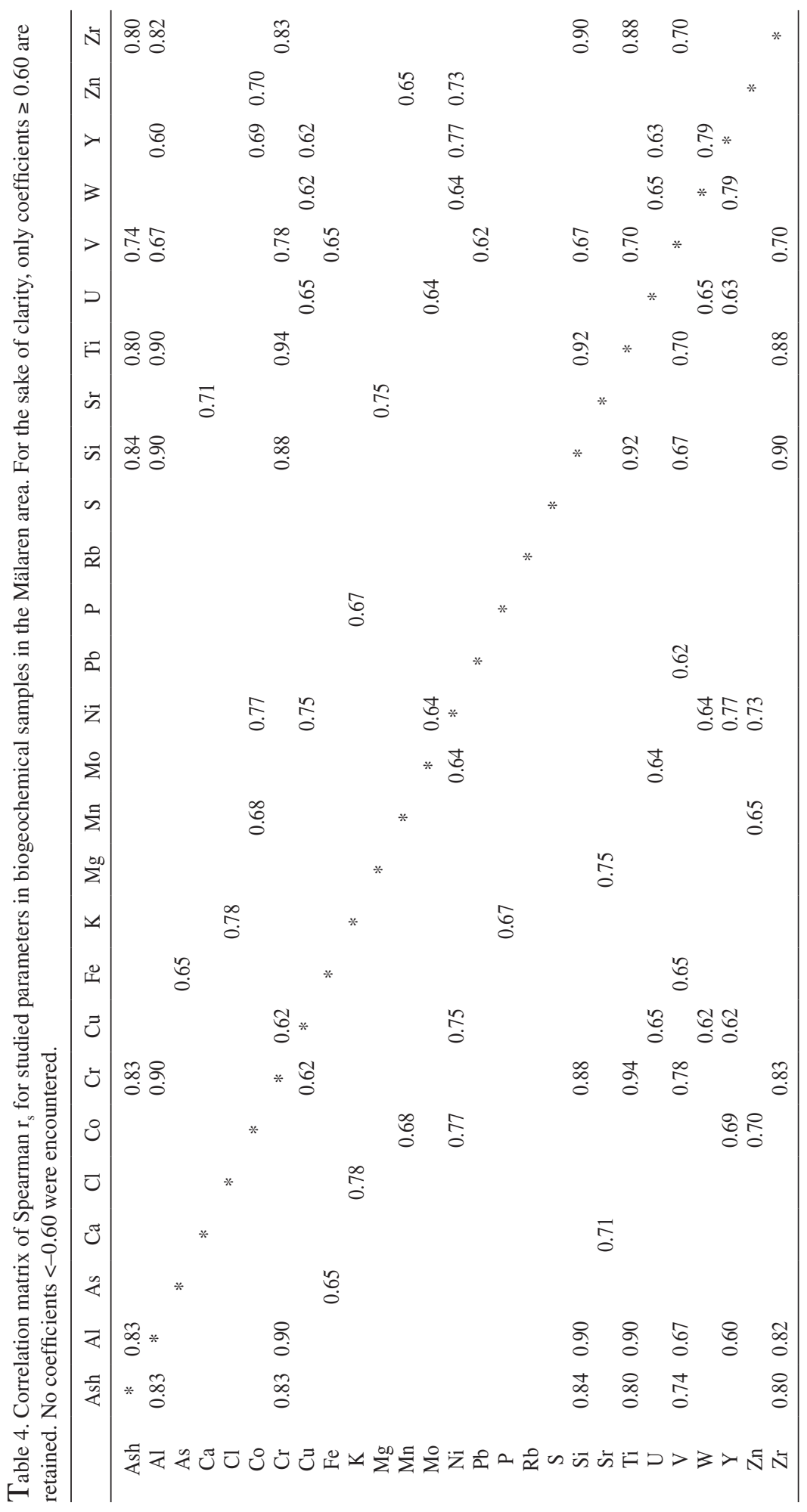


Vol. 14 (2005): 83-97.

Table 5. Ratios between median concentrations of elements and ash in biogeochemical samples for the entire population and median concentrations in subgroups according to type of Quaternary deposit at the sampling site in the Lake Mälaren area. Values $\geq 1.50$ and $\leq 0.50$ highlighted in bold.

\begin{tabular}{|c|c|c|c|c|c|c|c|c|c|}
\hline & Peat & Bedrock & Sand & Till & Silt & $\begin{array}{c}\text { Over- } \\
\text { bank }\end{array}$ & $\begin{array}{c}\text { Glacial } \\
\text { clay }\end{array}$ & $\begin{array}{c}\text { Postglacial } \\
\text { clay }\end{array}$ & $\begin{array}{c}\text { Gyttja } \\
\text { containing } \\
\text { sediments }\end{array}$ \\
\hline Ash & 0.82 & 0.94 & 0.88 & 0.94 & 1.00 & 1.09 & 0.97 & 1.06 & 1.24 \\
\hline $\mathrm{Al}_{2} \mathrm{O}_{3}$ & 0.66 & 1.16 & 0.86 & 0.90 & 1.11 & 1.15 & 1.00 & 1.06 & 1.42 \\
\hline As & 0.99 & 0.68 & 0.69 & 0.66 & 0.78 & 0.99 & 0.94 & 1.25 & 1.23 \\
\hline $\mathrm{CaO}$ & 0.76 & 1.09 & 1.15 & 0.99 & 0.90 & 1.11 & 1.03 & 1.04 & 0.93 \\
\hline $\mathrm{Cl}$ & 0.77 & 0.83 & 0.79 & 0.83 & 0.66 & 0.65 & 1.03 & 1.25 & 1.72 \\
\hline $\mathrm{Co}$ & 0.75 & 0.90 & 0.85 & 0.94 & 0.97 & 1.22 & 0.86 & 1.21 & 2.28 \\
\hline $\mathrm{Cr}$ & 0.70 & 1.23 & 0.75 & 0.82 & 1.07 & 1.21 & 0.98 & 1.19 & 1.47 \\
\hline $\mathrm{Cu}$ & 0.78 & 0.93 & 0.71 & 0.75 & 0.66 & 1.03 & 0.97 & 1.24 & 2.27 \\
\hline $\mathrm{Fe}_{2} \mathrm{O}_{3}$ & 1.17 & 0.80 & 0.95 & 0.93 & 1.03 & 0.89 & 0.91 & 1.06 & 1.28 \\
\hline $\mathrm{K}_{2} \mathrm{O}$ & 0.76 & 0.93 & 0.68 & 0.82 & 0.86 & 0.97 & 1.07 & 1.18 & 1.25 \\
\hline $\mathrm{MgO}$ & 0.70 & 0.98 & 0.88 & 0.86 & 0.91 & 1.10 & 1.09 & 1.19 & 1.07 \\
\hline $\mathrm{MnO}$ & 0.41 & 0.62 & 0.76 & 1.07 & 0.52 & 1.50 & 1.03 & 1.26 & 0.90 \\
\hline Mo & 0.84 & 0.78 & 0.87 & 0.73 & 0.72 & 0.99 & 0.88 & 1.19 & 1.78 \\
\hline $\mathrm{Ni}$ & 0.56 & 0.79 & 0.68 & 0.63 & 0.70 & 1.74 & 0.88 & 1.59 & 3.16 \\
\hline $\mathrm{Pb}$ & 1.08 & 1.12 & 1.01 & 1.08 & 1.19 & 0.78 & 0.96 & 0.95 & 1.10 \\
\hline $\mathrm{P}_{2} \mathrm{O}_{5}$ & 0.72 & 0.94 & 0.67 & 0.80 & 0.87 & 1.19 & 1.01 & 1.33 & 1.12 \\
\hline $\mathrm{Rb}$ & 0.94 & 1.16 & 0.81 & 0.95 & 1.14 & 1.08 & 1.04 & 1.02 & 0.95 \\
\hline $\mathrm{S}$ & 0.98 & 0.87 & 0.85 & 0.82 & 0.95 & 0.86 & 0.87 & 1.20 & 1.62 \\
\hline $\mathrm{SiO}_{2}$ & 0.80 & 1.10 & 0.79 & 0.92 & 1.21 & 1.16 & 0.99 & 1.06 & 1.21 \\
\hline $\mathrm{Sr}$ & 0.70 & 1.10 & 0.91 & 0.89 & 1.19 & 1.11 & 1.05 & 1.11 & 0.95 \\
\hline $\mathrm{TiO}_{2}$ & 0.50 & 1.17 & 0.67 & 0.83 & 1.00 & 1.08 & 1.00 & 1.17 & 1.33 \\
\hline $\mathrm{U}$ & 0.47 & 0.51 & 0.75 & 0.71 & 0.58 & 0.96 & 1.04 & 1.25 & 1.76 \\
\hline V & 0.81 & 0.98 & 0.89 & 0.95 & 1.06 & 1.03 & 0.95 & 1.06 & 1.14 \\
\hline W & 0.55 & 0.63 & 0.78 & 0.90 & 0.85 & 0.95 & 0.98 & 1.29 & 2.33 \\
\hline $\mathrm{Y}$ & 0.67 & 0.91 & 0.85 & 0.96 & 0.78 & 1.25 & 0.95 & 1.18 & 2.28 \\
\hline $\mathrm{Zn}$ & 0.71 & 0.98 & 0.92 & 0.83 & 0.99 & 1.68 & 0.97 & 1.13 & 1.79 \\
\hline $\mathrm{Zr}$ & 0.72 & 0.98 & 0.92 & 0.91 & 1.38 & 1.05 & 1.02 & 1.06 & 1.05 \\
\hline $\mathrm{n}$ & 167 & 45 & 92 & 169 & 31 & 24 & 304 & 442 & 96 \\
\hline
\end{tabular}

found for $\mathrm{Cu}, \mathrm{Ni}$ and Y. Furthermore, Eriksson et al. (1997) also reported a pattern for $\mathrm{Pb}$ in agricultural soils (top- and subsoil samples) that strongly resembles $\mathrm{Cu}, \mathrm{Ni}$ and $\mathrm{Y}$ in biogeochemical samples. The lack of spatial correlation for $\mathrm{Pb}$ suggests that biogeochemical samples in the area actually reflect concentrations dissolved in stream water, not minerogenic $\mathrm{Pb}$. Additionally, several elements (typical for AS influenced stream water in Finland) in some of the samples were very strongly enriched in the biogeochemical samples, compared with naturally occurring soils. It is therefore concluded that elevated concentrations in the samples were caused by the occurrence of elevated, bioavailable contents in stream water due to enhanced leaching of AS soils.

\section{The Skellefteå area}

Only 34 soil samples other than tills have been sampled and analysed in this area. More than one third (13) are situated in clay. These were compared to postglacial clays from the Mälaren region. Most elements had approximately 1.5-2 times higher concentrations in the Mälaren area. Only As, Mo and $\mathrm{W}$ had higher concentrations in the Skellefteå area, which in the case of As is supported by results reported by Eriksson et al. (1997). The median $\mathrm{pH}$ value was 1.3 units lower than in the Mälaren area (5.3 and 6.6, respectively). Glacial tills in the Skellefteå area are usually low in most metals (Lax, unpublished results) and are not likely to contribute significantly to levels in stream water. 


\section{Lax, K. Stream plant chemistry as indicator of acid sulphate soils}

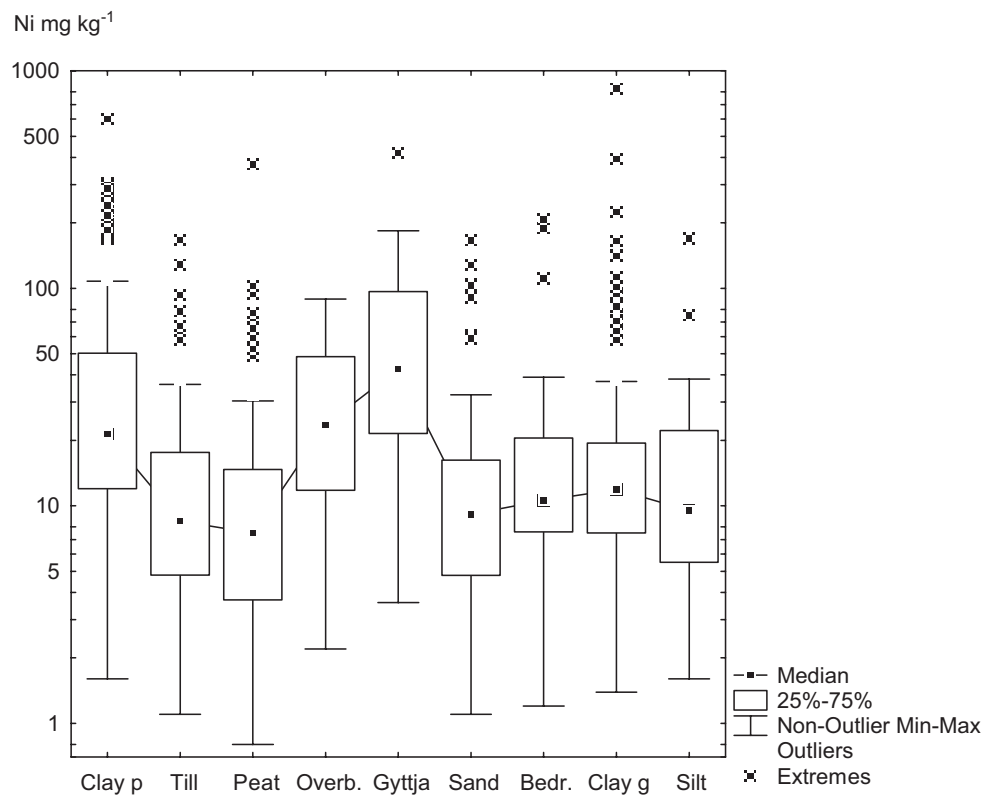

Fig. 3. Box plot of Ni in biogeochemical samples, grouped according to type of Quaternary deposit at sampling site. Clay $\mathrm{p}=$ postglacial clay, Clay $\mathrm{g}=$ glacial clay.
The majority (651) of the biogeochemical samples could be successfully classified as being situated in one of the major Quaternary deposits in the area. For simplification, deposits consisting of coarse sediments were treated as "sand" and "coarse sediments", rather than the original classifications. Samples that could not be classified were either from areas not covered by Quaternary mapping, or belonged to poorly represented units (e.g. three samples were from "bedrock").

The composition of biogeochemical samples in the Skellefteå area (Table 6) followed a surprisingly similar pattern to that found in the Mälardalen area (Table 5). When compared to the median value for the entire population, concentrations in clay-area samples were more than twice as high for $\mathrm{Ni}, \mathrm{W}, \mathrm{Cu}, \mathrm{Y}, \mathrm{Mo}$ and $\mathrm{U}$. Lead was even more clearly impoverished than in the Mälaren region. The only major discrepancies were As and $\mathrm{Cl}$. Higher natural As contents in tills from the area may well be the main reason for the comparatively low median value for that element. In the Mälaren region the median value was only $5.9 \mathrm{mg} \mathrm{kg}^{-1}$, approximately $25 \%$ of the corresponding value for the Skellefteå region $\left(23.3 \mathrm{mg} \mathrm{kg}^{-1}\right)$. The median $\mathrm{Cl}$ content in the Skellefteå area (clay-group samples) was less than $10 \%$ of the median for gyttjagroup samples from the Mälaren area. The large discrepancy for $\mathrm{Cl}$ remains to be explained.

\section{Discussion}

Roots of aquatic plants accumulate a number of elements in water draining active AS soils. This feature can be used to map the spatial distribution of such soils, and to locate areas with exceptional loadings of metals. Maps based on single-element concentrations in biogeochemical samples may be misleading, however, as other sources (e.g. pollution, mineralisations) are also likely to cause elevated contents. The use of ratio maps, e.g. Ni:Pb or $\mathrm{Y}: \mathrm{Pb}$, is a better solution. The origin of elevated levels of Y needs further studies. Yttrium is an element rarely focussed on in environmental geochemistry, but evidence from this study and studies in Finland (Åström and Åström 1997) indicate 
Vol. 14 (2005): 83-97.

Table 6. Ratios between median concentrations of elements and ash in biogeochemical samples for the entire population and median concentrations in subgroups according to type of Quaternary deposit at the sampling site in the Skellefteå area. Values $\geq 1.50$ and $\leq 0.50$ highlighted in bold.

\begin{tabular}{|c|c|c|c|c|c|c|c|}
\hline & Peat & Sand & $\begin{array}{c}\text { Coarse } \\
\text { sediments }\end{array}$ & Till & Silt & Clay-silt & Clay \\
\hline Ash & 0.84 & 1.02 & 1.11 & 0.93 & 0.96 & 1.16 & 1.19 \\
\hline $\mathrm{Al}_{2} \mathrm{O}_{3}$ & 0.85 & 1.11 & 1.07 & 0.82 & 1.15 & 1.19 & 1.70 \\
\hline As & 0.94 & 0.95 & 0.46 & 1.32 & 0.81 & 1.52 & 0.78 \\
\hline $\mathrm{CaO}$ & 0.95 & 1.10 & 1.13 & 0.91 & 1.39 & 0.79 & 0.86 \\
\hline $\mathrm{Cl}$ & 0.68 & 1.43 & 1.35 & 1.08 & 1.64 & 0.66 & 0.51 \\
\hline Co & 0.82 & 0.99 & 1.07 & 0.95 & 1.19 & 0.82 & 1.58 \\
\hline $\mathrm{Cr}$ & 0.84 & 1.06 & 0.79 & 0.89 & 1.02 & 1.19 & 1.41 \\
\hline $\mathrm{Cu}$ & 0.88 & 1.02 & 0.62 & 0.87 & 1.16 & 1.07 & 2.36 \\
\hline $\mathrm{Fe}_{2} \mathrm{O}_{3}$ & 0.92 & 0.92 & 1.26 & 1.00 & 0.82 & 1.35 & 1.51 \\
\hline $\mathrm{K}_{2} \mathrm{O}$ & 0.81 & 1.03 & 1.01 & 0.94 & 1.19 & 0.97 & 1.00 \\
\hline $\mathrm{MgO}$ & 0.77 & 1.15 & 1.17 & 0.85 & 1.65 & 0.77 & 1.08 \\
\hline $\mathrm{MnO}$ & 0.87 & 1.06 & 2.35 & 0.92 & 1.60 & 0.34 & 0.88 \\
\hline Mo & 1.08 & 0.82 & 0.80 & 1.00 & 0.87 & 0.73 & 2.01 \\
\hline $\mathrm{Ni}$ & 0.68 & 0.98 & 0.78 & 0.79 & 1.30 & 1.16 & 3.47 \\
\hline $\mathrm{Pb}$ & 1.18 & 0.95 & 1.52 & 1.18 & 0.68 & 1.02 & 0.52 \\
\hline $\mathrm{P}_{2} \mathrm{O}_{5}$ & 0.77 & 0.96 & 0.72 & 0.89 & 1.22 & 1.34 & 1.21 \\
\hline $\mathrm{Rb}$ & 0.93 & 1.05 & 1.10 & 0.90 & 1.18 & 0.94 & 0.80 \\
\hline $\mathrm{S}$ & 0.94 & 1.05 & 0.72 & 0.91 & 0.96 & 1.57 & 1.77 \\
\hline $\mathrm{SiO}_{2}$ & 0.93 & 1.08 & 1.33 & 0.80 & 1.18 & 1.15 & 1.25 \\
\hline $\mathrm{Sr}$ & 0.85 & 1.17 & 0.88 & 0.92 & 1.45 & 0.76 & 0.91 \\
\hline $\mathrm{TiO}_{2}$ & 0.85 & 1.09 & 0.90 & 0.73 & 1.26 & 1.28 & 1.26 \\
\hline $\mathrm{U}$ & 0.94 & 1.28 & 0.84 & 0.81 & 1.42 & 0.96 & 2.44 \\
\hline V & 0.84 & 1.18 & 0.83 & 0.99 & 0.90 & 1.06 & 1.23 \\
\hline W & 0.85 & 1.12 & 1.07 & 0.92 & 1.17 & 1.03 & 2.00 \\
\hline $\mathrm{Y}$ & 0.80 & 1.00 & 0.71 & 0.84 & 1.28 & 0.95 & 2.51 \\
\hline $\mathrm{Zn}$ & 0.93 & 1.00 & 0.93 & 0.89 & 1.19 & 0.69 & 1.55 \\
\hline $\mathrm{Zr}$ & 0.74 & 1.33 & 0.76 & 0.66 & 1.40 & 1.15 & 1.03 \\
\hline $\mathrm{n}$ & 122 & 134 & 18 & 214 & 91 & 16 & 53 \\
\hline
\end{tabular}

that for some reason, $\mathrm{Y}$ is mobilised in AS environments. This is puzzling because $\mathrm{Y}$ is generally considered to have very low mobility (Reimann and Caritat 1998) regardless conditions (oxidising/ reducing, acid/neutral/alkaline). A map of the $\mathrm{Ni}$ : $\mathrm{Pb}$ ratio in both study areas is presented in Fig. 4 . The spatial relationship between elevated ratios and postglacial, fine-grained sediments is excellent; very few samples with an $\mathrm{Ni}: \mathrm{Pb}$ ratio exceeding 2 occur in areas where such sediments have not been found. Furthermore, in some areas where extensive areas of AS soils are known to cause elevated metal contents in streams, the ratio exceeds 16.

In addition, the results show that several potentially harmful elements $(\mathrm{Ni}, \mathrm{Co}, \mathrm{Cu})$ are available to ecosystems to a higher degree in areas influenced by AS soils. The impact this has on the biota is not known, but may be assumed to be deleterious. The elevated levels stored in aquatic roots probably exacerbate the consequences of occasional occurrence of water with low $\mathrm{pH}$ and elevated metal concentrations. Although roots act as barriers to many potentially harmful elements (Kabata-Pendias and Pendias 1992), it has been shown by Yli-Halla and Palko (1987) that AS soils cause elevated concentrations of $\mathrm{Co}, \mathrm{Ni}, \mathrm{Cr}$ and $\mathrm{Al}$ in timothy (Phleum pratense L.), and of $\mathrm{Co}, \mathrm{Fe}, \mathrm{Mn}$ and $\mathrm{Ni}$ in grains from oats (Avena sativa L.). According to Palko and Yli-Halla (1988, 1990), total contents do not differ significantly, and the enrichment is due to elevated leachability of AS soils 


\section{AGRICULTURAL AND FOOD SCIENCE}

Lax, K. Stream plant chemistry as indicator of acid sulphate soils
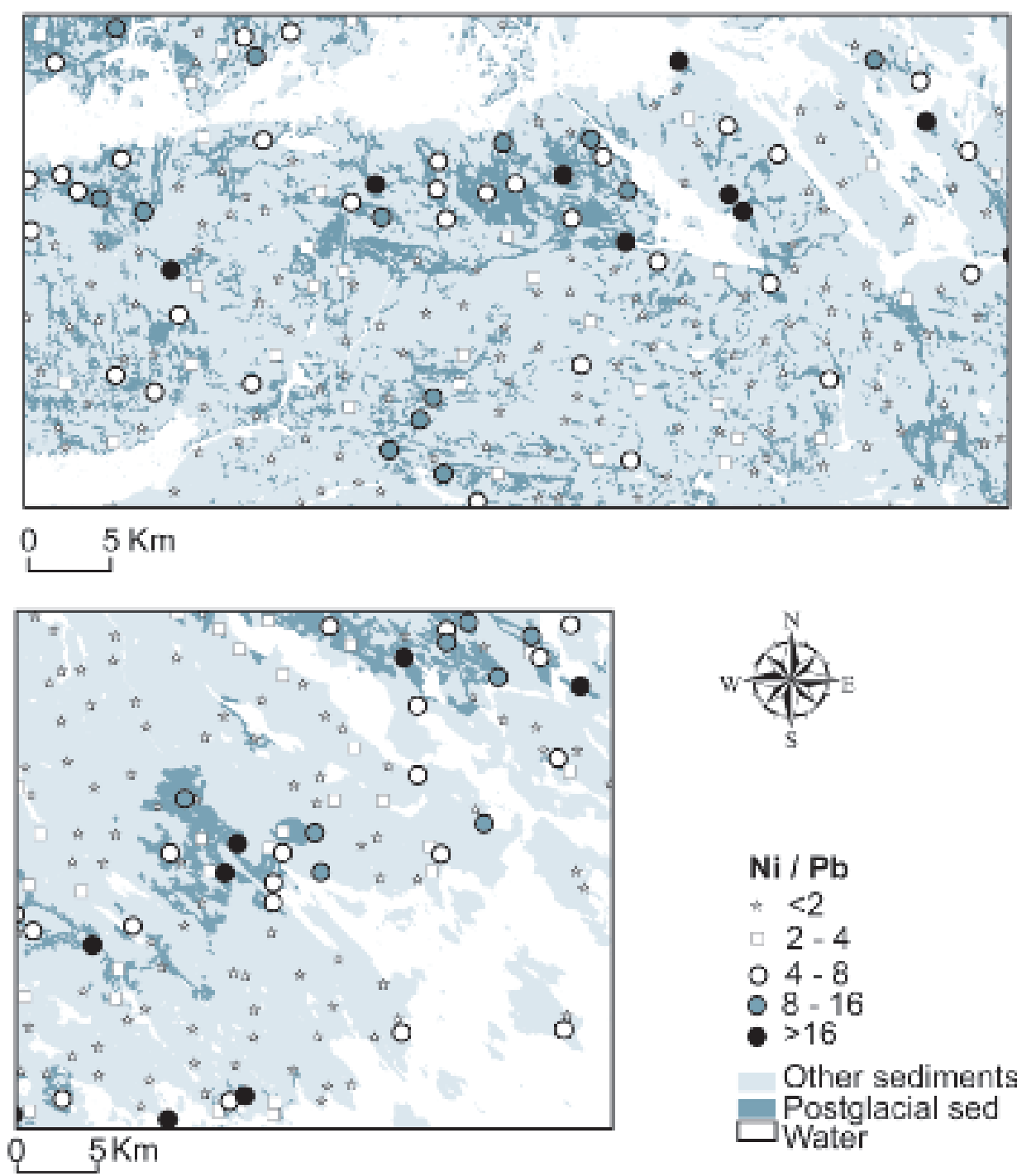

$\mathrm{Ni} / \mathrm{Pb}$

$*<2$

ㅁ 2 - 4

○ $4-8$

$8-16$

- $>16$

Other sediments

Postglacial sed

Water

Fig. 4. Map of selected areas within the Mälaren (upper) and Skellefteå (lower) areas. Quaternary geology simplified from databases at $\mathrm{SGU}$, with symbol maps of $\mathrm{Ni} / \mathrm{Pb}$ ratios in biogeochemical samples superimposed.

compared to other soils. Some species of Carex have been the subject of studies regarding phytoremediation, e.g. Carex rostrata (Stoltz and Greger 2002). Metal enrichment in aerial parts of plants with roots submerged in water derived from leaching of AS soils cannot be excluded, but elucidation of this question requires further investigation.

\section{References}

Andersson, A., Gustafson, A. \& Torstensson, G. 1988. Removal of trace elements from arable land by leaching. Swedish University of Agricultural Sciences, Department of Soil Sciences, Division of Water Management, Ekohydrologi 26: 13-22. 
Vol. 14 (2005): 83-97.

Andersson, M. 2004. Geokemiska kartan, markgeokemi. Metaller i morän och andra sediment Västra Mälardalen med Västerås tätort. Geological Survey of Sweden. Serie Gk 4. Uppsala. 121 p. (In Swedish with English summary).

Åström, M. 1996. Geochemistry, chemical reactivity and extent of leaching of sulphide-bearing fine-grained sediments in Southern Ostrobothnia, Western Finland. (PhD thesis). Åbo Akademi University, Åbo. 44 p.

Åström, M. \& Åström, J. 1997. Geochemistry of stream water in a catchment in Finland affected by sulphidic fine sediments. Applied Geochemistry 12: 593-605.

Åström, M. \& Deng, H. 2003. Assessment of the mobility of trace elements in acidic soils using soil and stream geochemical data. Geochemistry - exploration, environment, analysis, 3: 197-203.

Brundin, N.H., Ek, J.I. \& Selinus, O.C. 1987. Biogeochemical studies of plants from stream banks in northern Sweden. Journal of Geochemical Exploration 27: 157188.

Brundin, N.H. 1980. Aspects of geomedical problems from a biogeomedical point of view. In: Låg, J. (ed.). Geomedical aspects in present and future research. Universitetsforlaget, Oslo. p. 35-37.

Ekström, G. 1953. Åkermarkens matjordstyper. In: Atlas över Sverige, 63-64: 1-6. Svenska Sällskapet för Antropologi och Geografi. Generalstabens Litografiska Anstalts Förlag, Stockholm.

Eriksson, J., Andersson, A. \& Andersson, R. 1997. Current status of Swedish arable soils. Swedish Environmental Protection Agency, Report 4778. Stockholm. 59 p.

Fredén, C. (ed.) 1994. Geology. National Atlas of Sweden. Stockholm. 208 p.

Holmberg, J., Ohlsson, S.-Å. \& Ressar, H. 1999. Tungmetaller i bäckvattenväxter. Mellersta Dalarna. Geological Survey of Sweden, Serie Gk 1. Uppsala. 44 p. (In Swedish with English summary).

Kabata-Pendias, A. \& Pendias, H. 1992. Trace elements in soils and plants. 2nd ed. CRC Press, Inc. Florida. $365 \mathrm{p}$.

Lax, K. 2005. Geokemiska kartan, markgeokemi. Metaller i morän i Västerbottens län. Geological Survey of Sweden. Serie K. (In press, in Swedish with English summary).

Lax, K. \& Selinus, O. 2005. Geochemical mapping at the Geological Survey of Sweden. Geochemistry - exploration, environment, analysis. In press.

Lång, L.-O. \& Thunholm, B. 2002. Geologisk information och modellering i avrinningsområden. Slutrapport för FoU-projekt 5273. SGU-rapport 2002:43. Geological Survey of Sweden, Uppsala. $48 \mathrm{p}$.

Manngård, B. 1997. Impact of cultivated acid sulphate soils on surface water geochemistry in two small catchments in southern Lake Mälaren. Swedish University of Agricultural Sciences, Department of Soil Sciences. Undergraduate Thesis No. $28.54 \mathrm{p}$.

Melkerud, P.A., Olsson, M.T. \& Rosén, K. 1992. Geochemical atlas of Swedish forest soils. Swedish University of Agricultural Sciences, Reports in forest ecology and forest soils 65 . Uppsala. $85 \mathrm{p}$.
Öborn, I. 1989. Properties and classification of some acid sulfate soils in Sweden. Geoderma 45: 197-219.

Öborn, I. 1994. Morphology, chemistry, mineralogy and fertility of some acid sulfate soils in Sweden (PhD thesis). Swedish University of Agricultural Sciences, Department of Soil Sciences. Reports and Dissertations 18. Uppsala.

Öborn, I. \& Andersson, P. 1999. Sulfidlerornas betydelse för stora tungmetallflöden i vissa sedimentområden. Geological Survey of Sweden. Research report Dnr 943/96.

Österholm, P. \& Åström, M. 2002. Spatial trends and losses of major and trace elements in agricultural acid sulphate soils distributed in the artificially drained Rintala area, W. Finland, Applied Geochemistry 17, 9: 12091218.

Palko, J. \& Yli-Halla, M. 1988. Solubility of Co, Ni, and Mn in some extractants in a Finnish acid sulphate soil area. Acta Agriculturae Scandinavica 38: 153-158.

Palko, J. \& Yli-Halla, M. 1990. Solubility of Al, Cr, Cu and Zn in soils from a Finnish acid sulphate soil area. Acta Agriculturae Scandinavica 40: 117-127.

Reimann, C. \& Caritat, P. de 1998. Chemical elements in the environment - Factsheets for the geochemist and environmental scientist. Springer Verlag, Berlin-Heidelberg-New York, $398 \mathrm{p}$.

Reimann, C. (ed.), Siewers, U., Tarvainen, T., Bityukova, L., Eriksson, J., Giucis, A., Gregorauskiene, V., Lukashev, V.K., Matinian, N.N. \& Pasieczna, A. 2003. Agricultural soils in Northern Europe: A Geochemical Atlas. Sonderhefte Reihe D - Geologisches Jahrbuch Sonderhefte, Reihe D, Heft SD5. 279 p. + 1 CD-ROM.

Rühling, Å., Steinnes, E. \& Berg, T. 1996. Atmospheric heavy metal deposition in Northern Europe 1995. Nordic Council of Ministers, Nordic Publishing House, Nord 1996: 37.46 p.

SCB 2004. Markanvändningen i Sverige. Statistics Sweden. 4th ed. ISBN 91-618-1174-2. 143 p. (In Swedish).

Selinus, O. 1983. Regression analysis applied to interpretation of geochemical data at the Geological Survey of Sweden. In: Howarth, R.J. (ed.). Handbook of geochemistry, Part 2: Statistics and data analysis in geochemical prospecting. Elsevier, Amsterdam. p. 293301.

Smedley, P. \& Kinniburgh, D.G. 2005. Arsenic in groundwater and the environment. In: Selinus, O. (ed.). Essentials of medical geology. Elsevier Academic Press, Amsterdam. p. 263-299.

Stoltz, E. \& Greger, M. 2002. Accumulation properties of As, $\mathrm{Cd}, \mathrm{Cu}, \mathrm{Pb}$ and $\mathrm{Zn}$ by four wetland plant species growing on submerged mine tailings. Environmental and Experimental Botany 47, 3: 271-280.

Svantesson, S.-I. 1991. Description to the Quaternary map Enköping NO. SGU Serie Ae No. 110. Geological Survey of Sweden, Uppsala, $85 \mathrm{p}$.

Yli-Halla, M. \& Palko, J. 1987. Mineral element content of oats (Avena sativa L.) in an acid sulphate soil area of Tupos village, northern Finland. Journal of Agricultural and Food Science in Finland 59: 73-78. 